Printing is for personal, private use only. No part of this book may be reproduced or transmitted without publisher's prior permission. Violators will be prosecuted.

\title{
Multimedia Talempong Pacik learning: Virtual instrument based on Android
}

\author{
B.F.F. Zerky \& K.S. Astuti \\ Universitas Negeri Yogyakarta, Yogyakarta, Indonesia
}

\begin{abstract}
This paper explains the process of developing Talempong Pacik multimedia learning on android-based smart phones, from the production process to product validation. Research and development adapted from Borg \& Gall, and Allesi \& Trollip include planning, design, development, staging and production. The research and development aim: (1) Produce android-based Talempong Pacik multimedia learning for middle school (SMP) VIII grade students; (2) Test the feasibility of Android-based Talempong Pacik multimedia learning for learning grade VIII SMP students; (3) Find out the attraction product developed; (4) Find out whether students can use Talempong Pacik correcrlt after using the product developed. In the development process using Adobe Flash Professional software and Adobe Animate software, but this software has the disadvantage of being delayed in the Talempong Pacik android game that is ready to be validated by experts. In the end the author used the Android Studio software and the problem found was solved.
\end{abstract}

\section{INTRODUCTION}

Talempong Pacik is a traditional musical instrument of the Minangkabau community of West Sumatra. Bahar (2003) Talempong music is the only cultural music that can be found throughout Minangkabau region.

Ikhsan \& Astuti (2018) described that Talempong a small gong-shaped instrument made of brass, tin and copper. A song in the talempong pacik game is produced through game interactions of various rhythmic patterns and motives inherent in the three rhythmic units and various rhythmic patterns and motives that are mutually unequal or different from one another with technical games interlocking. Children in middle schools in Padang studied Talempong Pacik, but not all schools have Talempong Pacik. For schools that have Talempong Pacik, they can study and practice while schools that do not only learn theory. Another problem is the absence of traditional music teachers, especially for Talempong Pacik. The author found that there is potential in the fact that most students have an Android smartphone.

The author thinks these problems and potential are important to solve and develop. Talempong Pacik virtual traditional musical instrument is as a simulation tool to play the real Talempong Pacik by utilizing an Android smart phone and opening up the potential of education to utilize smart phones in music learning, especially in the city of Padang. So students can practice learning material in class.

\section{LITERATURE REVIEW}

There is previous research that is relevant to this research; Mona (2015) entitled "Multimedia Interaktif Talempong Pacik sebagai Media Pembelajaran Seni di SMP Negeri 3 Kota Solok"(Interactive Multimedia Talempong Pacik as Medium of Learning Arts at Junior School State 3 Kota Solok). This study was based on the problems (1) the unavailability of talempong pacik school instruments, (2) teachers did not have an art background so it was impossible to teach pacik talempong 

prior permission. Violators will be prosecuted.

to students (3) lack of time in art teaching and culture. In the three problems that exist, teachers can utilize and empower technology to realize effective learning behaviour and increase the motivation to learn talempong, which is using interactive multimedia based talempong. It can be one of the solutions useful to support teachers, and helps students appreciate and express talempong pacik.

\section{RESEARCH METHODOLOGY}

\subsection{Research methods}

This type of research is development research to obtain a product. The product developed is a Talempong Pacik multimedia learning tool based on android. This research and development adapted from Borg \& Gall (1984), Allesi \& Trollip (2000) and modifications to R \& D artwork by Pradoko, et al (2014).

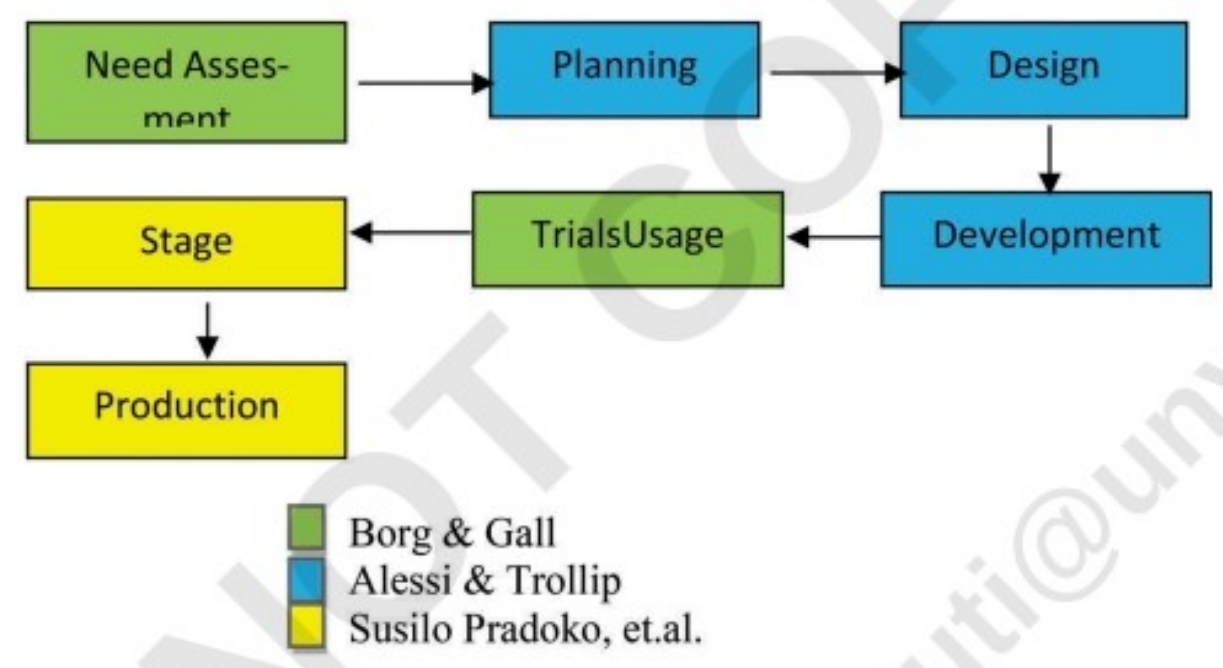

Figure 1. Stages of research and development.

In the needs assessment phase, researchers spent two semesters becoming music arts teachers at Padang State Middle School 5. Problems and potential found show that not all schools have Talempong Pacik and most students have an android smart phone. Another problem is that not all schools have music art teachers. In this step, the researchers also conducted brainstorming with several parties related to product development, so that it was developed in accordance with the results of the needs analysis. At the design stage, the product framework was developed such as flowcharts and storyboards. The framework contains full flow and multimedia content. The development step is the step of assembling all content that has been created and prepared into a multimedia product. After the product is ready, then alpha and beta testing stages are carried out which aim to assess the feasibility of the product, both in terms of appearance and content. The final step, conducting field testing in the school classroom and the Pongcikdroid performance, aimed to find out the effectiveness of multimedia on student learning outcomes.

Pongcikdroid is the concept of combining learning media using technology, which is the basis of the material taught to wit local wisdom in the form of traditional musical instruments. This multimedia was developed based on needs analysis in schools, so that learning materials were adjusted to the level of students' abilities. This multimedia contains material about Talempong Pacik; Pongcikdroid; learning objectives; the songs: Cak Din Din, Tigo Duo, Siamang Tagagau; instructions for playing Pongcikdroid; and Developer.

This multimedia characteristic was adjusted for grade VIII students, by displaying elements of the province of West Sumatra as the place of origin of Talempong Pacik. The opening music used was the song Cak Din Din. This aims to adjust between the background, nuances, and learning material provided. Here are some examples of multimedia displays: 
Printing is for personal, private use only. No part of this book may be reproduced or transmitted without publisher's prior permission. Violators will be prosecuted.

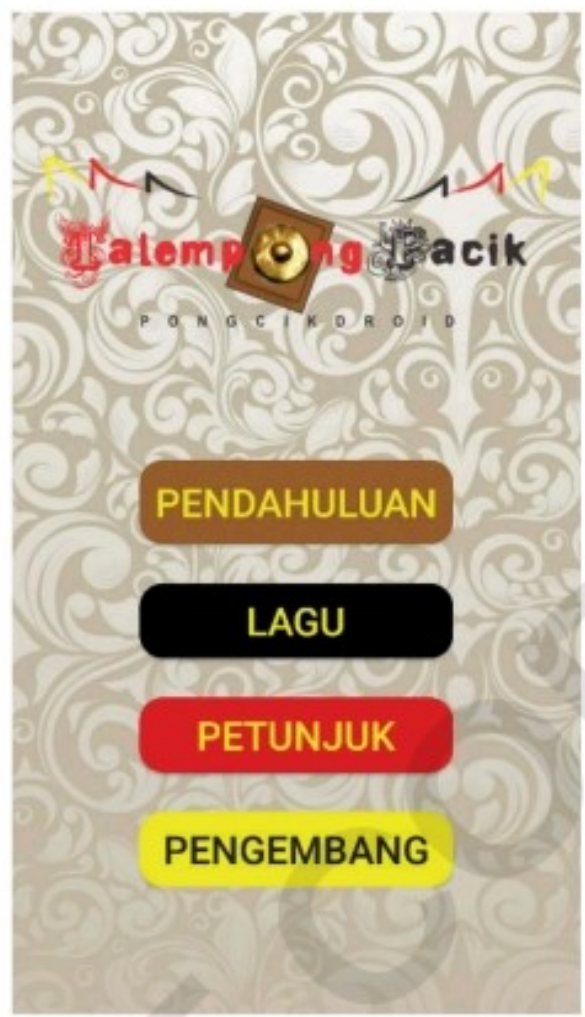

Figure 2. Home screen of pongcikdroid.

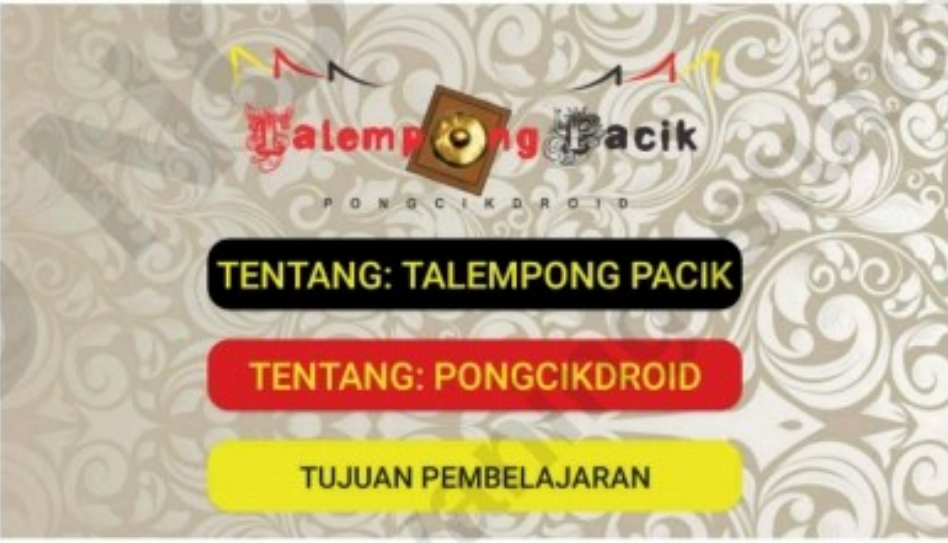

Figure 3. Menu preliminary.

\subsection{Data presentation techniques}

To test the feasibility of this learning tool, the validation step was taken by media experts and material experts. Previously, instruments had been prepared and validated which would be used by the two validators. Validation of media instruments and materials was prepared based on variables developed into relevant media and information materials. Assessment is done by setting values in the range 1-5 which are adapted from a scale of five, one of the most diverse can be seen in the following table:

After the two validators provide an assessment of the media and material, the next step is to calculate the average value of the assessment results. The average value is obtained based on the following formula:

Definition 1 (See [1]). The average number is denoted by $X$, symbol $\sum x$ is defined as the number of scores and symbol " $n$ " is defined for the number of questions. 
Printing is for personal, private use only. No part of this book may be reproduced or transmitted without publisher's prior permission. Violators will be prosecuted.

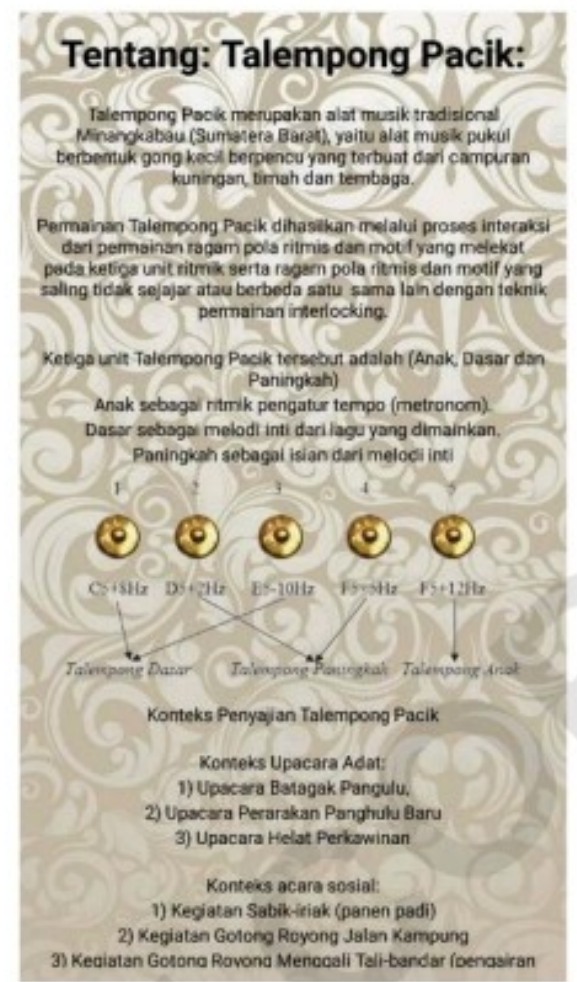

Figure 4. About talempong pacik.

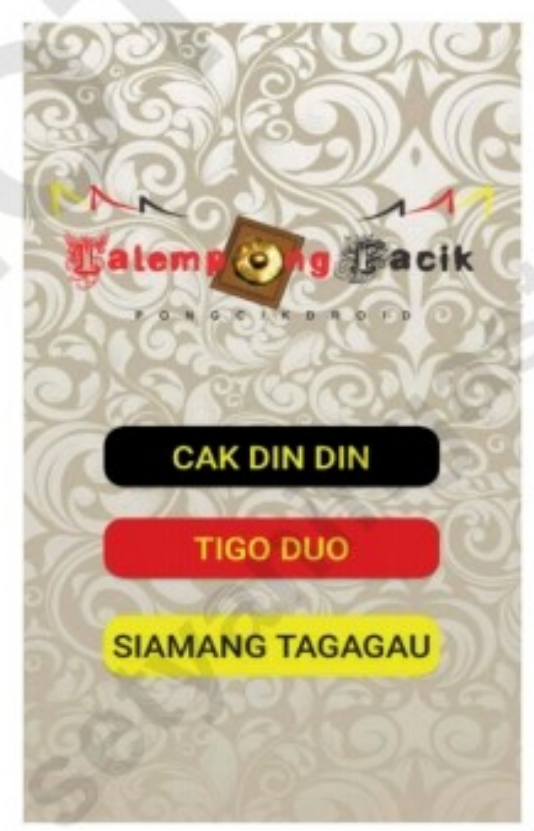

Figure 5. Song of talempong pacik on pongcikdroid.

$$
X=\frac{\sum X}{n}
$$

The results of the average scores that have been obtained are then converted into information in the form of qualitative data using five scale guidelines according to Sukardjo (2009: $84)$, which is shown in the following table: 

prior permission. Violators will be prosecuted.

Table 2. Guidelines to convert quantitative data to qualitative in five scales.

\begin{tabular}{llll}
\hline No & Score Range & Calculation Guide & Criteria \\
\hline 1 & $\mathrm{Mi}+1,80 \mathrm{Sbi}<\mathrm{X}$ & $\mathrm{X}>4,21$ & Very Good \\
2 & $\mathrm{Mi}+0,60 \mathrm{Sbi}<\mathrm{X} \leq \mathrm{Mi}+1,80 \mathrm{Sbi}$ & $3,40<\mathrm{X} \leq 4,21$ & Good \\
3 & $\mathrm{Mi}-0,60 \mathrm{Sbi}<\mathrm{X} \leq \mathrm{Mi}+0,06 \mathrm{Sbi}$ & $2,60<\mathrm{X} \leq 3,40$ & Sufficient \\
4 & $\mathrm{Mi}-1,80 \mathrm{Sbi}<\mathrm{X} \leq \mathrm{Mi}-0,06 \mathrm{Sbi}$ & $1,79<\mathrm{X} \leq 2,60$ & Less \\
5 & $\mathrm{X} \leq \mathrm{Mi}-1,80 \mathrm{Sbi}$ & $\mathrm{X} \leq 1,79$ & Very Less \\
\hline
\end{tabular}

Definition 2 (See Table 2). The scores achieved is denoted by $X$, symbol Mi is defined as the simulation of "1/2 (ideal maximum score + minimum score ideal)", and symbol Sbi is defined for the simulation of "1/6 (ideal maximum score - ideal minimum score)".

\section{RESULTS AND DISCUSSION}

\subsection{Result}

To determine the feasibility of the product in the media and the material aspects, the score for the assessment of media and material experts (validators) was changed to qualitative data using five scale guides. Multimedia will be declared feasible when getting the minimum result, corresponding to the criteria "Good" according to Table 2.

Dr. AM. Susilo Pradoko is a material expert in alpha testing (Lecturer in the Department of Music Education, Faculty of Language and Art, Yogyakarta State University). The assessment process was carried out on May 4, 2018, there were 3 (three) components in the assessment by material experts: the quality of learning, material content, and quality of presentation. These were developed into 20 items of statements, rated on a scale of 1-5.

Based on the assessment of material experts on the products developed, 72 values were obtained with an average score of 3.6 being in the criteria of "good". From the assessment the material expert stated that the material contained in the product was feasible to be developed.

Dr. Kusnadi, M.Pd is a media expert in the alpha test (Lecturer in the Department of Dance Education, Faculty of Language and Art, Yogyakarta State University). The assessment process was carried out on May 9, 2018, there were 3 (three) components in the assessment by material experts: the quality of learning, the content of the material and the quality of presentation. These were developed into 20 items of statements, scoring 1-5.

Based on the assessment of material experts on the products developed, the value of 95 was obtained with an average score of 4.75 being in the criteria of "very good". From the assessment material experts stated that the multimedia contained in the product was feasible to be developed.

\subsection{Discussion}

Material experts provide advice outside the application that has been developed in order to add the Learning Process Plan (Rencana Proses Pembelajaran/RPP) in learning to use the product[Nisak, 2013]. One piece of advice from media experts is that song scores are made bigger because they are considered too small. The developer has tried to revise this in accordance with the advice of media experts, but it cannot be done because the screen resolution on Android is not sufficient to be enlarged. If this change is forced it will make the layout on the screen display asymmetrical. Also students are still able to see the score despite its small resolution size.

Suggestions from media validators and material validators are very helpful in developing this product. Everything that has not been done on this final product will be tried to be better developed in the future. 


\section{CONCLUSION}

In today's modern era, technology is becoming more influential and can be developed into learning media, especially based on Android technology. Pongcikdroid is one way to simulate the real Talempong Pacik performance. There is a need to learn more about how to create multimedia that is good and effective, as well as the need to add more content to existing multimedia products. Multimedia Talempong Pacik Learning is a Virtual Instrument Based on Android can be use. However This media has many limitations, one of which is that it can only be used on Android. The advantages of this product must be mobile and can be played anytime and anywhere, and ensemble games can be played between offline virtual users. Researchers must be actively involved in the development of these so that multimedia learning in the art of music will be richer.

\section{REFERENCES}

Alessi, S. M., \& Trollip, S. R. (2000). Multimedia for learning: Methods and development. Allyn \& Bacon, Inc.

Bahar, M. (2017). Cultural Uniformity and Diversity of Talempong Music. The Social Sciences, 12 (10),1897-1910.

Borg, W. R., \& Gall, M. D. (1984). Educational research: An introduction.

Ikhsan, Y., \& Astuti, K. S. (2018). Efektivitas tradisional Talempong Pacik terhadap peningkatan disiplin, toleransi, dan kerjasama siswa. [Effectiveness of Talempong Pacik tradisional music instrument teaching to instil discipline, tolerance, and cooperation of students]. Harmoni Sosial: Jurnal Pendidikan IPS, $5(1), 57-66$.

Mona, D. (2016). Multimedia Interaktif Talempong Pacik Sebagai Media Pembelajaran Seni Di SMP N 3 Kota Solok [Talempong Pacik Interactive Multimedia as an Art Learning Media in Public Middle School 3 at Solok]. (Doctoral dissertation, Universitas Pendidikan Indonesia).

Nisak, K. (2013). Pengembangan perangkat pembelajaran IPA terpadu tipe connected pada materi pokok sistem ekskresi untuk kelas IX SMP[Developing of teaching and learning plan of sains for Junior School]. PENDIDIKAN SAINS, 1(01).

Pradoko, S., \& Priyanto, W. P. (2014). Rancang Bangun Musik Angklung Model SATB, Dasar Aransemen Model Orchestra [Design of SATB Angklung Music Model, Basic Arrangement of Orchestra Model]. Imaji, 14(1),90-97. 